\title{
Laminar Organization of the NMDA Receptor Complex within the Postsynaptic Density
}

\author{
Juli G. Valtschanoff and Richard J. Weinberg \\ Department of Cell Biology and Anatomy, University of North Carolina, Chapel Hill, North Carolina 27599
}

The NR2 subunit is an essential component of the NMDA receptor. Recent biochemical research has identified a number of molecules that can bind directly or indirectly to its cytoplasmic tail. These postsynaptic density (PSD) proteins play a role in intracellular signal transduction, and are implicated in synaptic plasticity and memory mechanisms. We performed systematic electron microscopic immunogold analysis in rat neocortex to determine the spatial organization of NR2, in relation to six other proteins thought to be involved in the NMDA receptor complex. Peak concentrations of each protein were within the PSD but in different "layers" of the density. In the axodendritic axis, gold particles coding for PSD-95 lay an average of $12 \mathrm{~nm}$ cytoplasmic to the extracellular face of the plasma membrane, very close to the $C$ terminal of NR2. Nitric oxide synthase lay $18 \mathrm{~nm}$ inside the membrane; the scaffolding proteins guanylate kinase-associated protein and Shank lay 24-26 nm inside the membrane; and CRIPT and dynein light chain, proteins that may link the complex to cytoskeletal elements, lay on the cytoplasmic side of the PSD, 29-32 nm inside the plasma membrane and extending into the spine cytoplasm. The supramolecular organization of these molecules may modulate intracellular transduction of NMDA-mediated signals.

Key words: scaffolding protein; PDZ domain; excitatory synapse; postembedding immunocytochemistry; cerebral cortex; PSD-95; nitric oxide synthase
The NMDA receptor is an oligomer comprising NR1 and NR2 subunits (Hollmann and Heinemann, 1994). Calcium ions flowing through the receptor pore can trigger intracellular biochemical cascades that underlie its key role in synaptic plasticity (Collingridge and Watkins, 1994; Dingledine et al., 1999). Immunogold electron microscopy reveals that NMDA receptor subunits concentrate at the postsynaptic membrane of most asymmetric synapses (Bernard and Bolam, 1998; Kharazia and Weinberg, 1999; Petralia et al., 1999; Takumi et al., 1999; Valtschanoff et al., 1999; Racca et al., 2000). This postsynaptic clustering might be explained by anchoring molecules found in the postsynaptic density (PSD) like PSD-95 (Cho et al., 1992; Kistner et al., 1993).

PSD-95 contains three PSD-95, DLG, Zo-1 (PDZ) domains (sites for protein-protein interaction) on its $\mathrm{N}$-terminal side and a guanylate kinase domain near its C terminal (Kennedy, 1997). Biochemical data suggest that PSD-95 can bind, via its PDZ1 and 2, to the C terminal of NR2 subunits (Kornau et al., 1995; Niethammer et al., 1996; Bassand et al., 1999) and, via PDZ3, to the protein CRIPT, which may link the NMDA receptor complex to the cytoskeleton (Niethammer et al., 1998; Passafaro et al., 1999). Yeast two-hybrid screens using the guanylate kinase domain of PSD-95 as bait pulled out guanylate kinase-associated protein (GKAP) (Kim et al., 1997), a protein that modulates NMDA channel conductance (Yamada et al., 1999). GKAP, in turn, can bind to dynein light chain (DLC), a subunit of motor proteins implicated in synaptic remodeling (Naisbitt et al., 2000), and to Shank, a protein that links the NMDA receptor complex to

Received May 22, 2000; revised Nov. 20, 2000; accepted Nov. 21, 2000.

This work was supported by National Institutes of Health Grants NS29879 and 39444 to R.J.W. We thank K. Phend for expert histological support and M. Sheng for his encouragement and careful critique of this manuscript.

Correspondence should be addressed to Dr. Juli Valtschanoff, Department of Cell Biology and Anatomy, CB\# 7090, University of North Carolina, Chapel Hill, NC 27599. E-mail: jval@med.unc.edu.

Copyright (C) 2001 Society for Neuroscience 0270-6474/01/211211-07\$15.00/0 metabotropic receptors, thus orchestrating functional interactions between metabotropic and ionotropic systems (Naisbitt et al., 1999; Tu et al., 1999).

PSD-95 knock-out mice retain functional postsynaptic NMDA receptors but exhibit aberrant long-term potentiation and learning deficits (Migaud et al., 1998). Thus, rather than merely anchoring the receptor, PSD-95 acts as a molecular scaffold to organize signaling cascades within the NMDA receptor complex (Ziff, 1997; Craven and Bredt 1998; O’Brien et al., 1998; Sprengel et al., 1998; Garner et al., 2000; Sheng and Pak, 2000) For example, the calcium-dependent enzyme neuronal nitric oxide synthase (nNOS), implicated in synaptic plasticity, can bind to PSD-95 (Brenman et al., 1996; Christopherson et al., 1999). Might nNOS be strategically positioned to detect $\mathrm{Ca}^{2+}$ entering through the NMDA pore?

Accumulating data on mechanisms underlying synaptic plasticity suggest that the NMDA receptor complex acts as a "molecular machine" (Malenka and Nicoll, 1999; Weng et al., 1999; Kennedy, 2000). Investigation of the Drosophila photoreceptor points to the functional significance of the supramolecular organization of analogous protein assemblies (Scott and Zuker, 1998; Tsunoda and Zuker, 1999). Molecular and biochemical studies can define the topology of protein interactions emanating from the cytoplasmic tails of NMDA receptor subunits, but they do not reveal its spatial geometry. Light microscopy lacks adequate resolution, and $\mathrm{x}$-ray crystallography is poorly suited for the study of membranebound supramolecular assemblies. By systematic use of quantitative immunogold electron microscopy, we provide new insight into the architecture of the NMDA receptor complex and demonstrate its laminar organization within the PSD.

\section{MATERIALS AND METHODS}

Tissue preparation. All procedures related to the care and treatment of animals were according to institutional and National Institutes of Health guidelines. Material from seven male Sprague Dawley rats (Charles 
Table 1. Primary antibodies used in the study

\begin{tabular}{lllll} 
Protein & Antigen $^{\mathrm{a}}$ & Antibody & Source & Characterized in \\
\hline Synaptophysin & $1-307(307)$ & SVP-38 & Sigma & Devoto and Barnstable (1987) \\
NR2A/B & $1408-1424(1424)$ & AB1548 & Chemicon & Petralia et al. (1994) \\
PSD-95 & $77-299(724)$ & $77-299$ & Upstate Biotechnology & Kim et al. (1995) \\
nNOS & $1-200(1429)$ & Z-RNN & Zymed & Christopherson et al. (1999) \\
CRIPT & $41-58(101)$ & $97 / 3$ & M. Sheng & Niethammer et al. (1998) \\
GKAP & $744-964(964)$ & C9589 & M. Sheng & Kim et al. (1997) \\
Shank & $469-691(1740)$ & $56 / 8$ & M. Sheng & Naisbitt et al. (1999) \\
DLC & $35-50(89)$ & 95.5 & M. Sheng & Naisbitt et al. (2000) \\
\hline
\end{tabular}

${ }^{a}$ Numbers identify position of antigen in the polypeptide chain. The total number of amino acids in the protein is in parentheses.

\begin{tabular}{|c|c|c|c|c|c|c|c|c|}
\hline Antigen & $\begin{array}{l}\mathrm{R} 1588 \\
\text { (E) }\end{array}$ & $\begin{array}{l}\text { R1672 } \\
\text { (L) }\end{array}$ & $\begin{array}{l}\text { R1677 } \\
\text { (E) }\end{array}$ & $\begin{array}{l}\text { R1682 } \\
\text { (E) }\end{array}$ & $\begin{array}{l}\text { R1697 } \\
\text { (E) }\end{array}$ & $\begin{array}{l}\text { R1726 } \\
\text { (E) }\end{array}$ & $\begin{array}{l}\text { R1779 } \\
\text { (L) }\end{array}$ & Total \\
\hline NR2 & $17(24)$ & & & & $31(99)$ & $25(88)$ & & 73 (211) \\
\hline PSD-95 & 17 (59) & $30(69)$ & & & $26(78)$ & & & 73 (206) \\
\hline nNOS & $22(35)$ & & & & $39(73)$ & & $7(9)$ & 68 (117) \\
\hline CRIPT & $18(33)$ & & $10(47)$ & & $16(30)$ & & & 44 (110) \\
\hline GKAP & $11(29)$ & $13(43)$ & & & $15(35)$ & & & 39 (107) \\
\hline Shank & $13(52)$ & & & & $13(51)$ & & $17(113)$ & 43 (216) \\
\hline DLC & $17(41)$ & & $13(51)$ & $15(87)$ & $11(37)$ & & & $56(216)$ \\
\hline
\end{tabular}

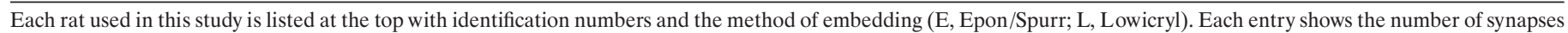
and, within parentheses, the number of gold particles for each postsynaptic antigen; totals are listed on the right.

River, Wilmington, MA; 220-400 gm) was used for this study. After deep anesthesia was induced with sodium pentobarbital $(60 \mathrm{mg} / \mathrm{kg}$, i.p.), rats were intracardially perfused with heparinized saline followed by 500 $\mathrm{ml}$ of fixative. Fixative was a mixture of freshly depolymerized $2-4 \%$ paraformaldehyde and 2-2.5\% glutaraldehyde in phosphate buffer (PB; $0.1 \mathrm{M}), \mathrm{pH} 7.4$; in some cases, $0.1 \%$ picric acid was added in an effort to improve membrane preservation. However, none of the modifications tested provided any clear advantage over $2 \%$ paraformaldehyde and $2 \%$ glutaraldehyde. Brains were removed and stored in cold PB; brains were post-fixed in the same fixative for $2-16 \mathrm{hr}$. Coronal $50 \mu \mathrm{m}$ sections were cut on a Vibratome and collected in cold PB.

EM immunolabeling. Sections were processed for osmium-free embedment according to the method of Phend et al. (1995). For epoxy embedment, dehydrated sections were immersed in propylene oxide and infiltrated with a mixture of Epon and Spurr resins [Electron Microscopy Sciences (EMS), Fort Washington, PA] and then sandwiched between strips of Aclar plastic film (EMS) and polymerized at $60^{\circ} \mathrm{C}$ for $36 \mathrm{hr}$. For acrylic embedment, dehydrated sections were infiltrated with Lowicryl HM-20 (EMS), sandwiched in Aclar, and polymerized at $-10^{\circ} \mathrm{C}$ for $48 \mathrm{hr}$ under UV illumination. After polymerization, chips including layers 2-3 of the somatic sensory cortex were cut from the wafers and glued onto blank resin blocks with cyanoacrylate. Chips from different animals were of consistent size and orientation.

Thin $(\sim 100 \mathrm{~nm})$ sections were cut and collected on nickel mesh grids and processed for immunogold labeling as described previously (Phend et al., 1992, 1995). Briefly, after treatment with 4\% para-phenylenediamine in Tris-buffered saline $[0.1 \mathrm{~m}$ Tris, $\mathrm{pH} 7.6$, with $0.005 \%$ Tergitol NP-10 (TBST)], grids were incubated overnight at $37^{\circ} \mathrm{C}$ in primary antibody (Table 1). Grids were then transferred to TBST, $\mathrm{pH}$ 8.2 , incubated for $1 \mathrm{hr}$ in the $\mathrm{F}(\mathrm{ab}) 2$ fragment of IgG conjugated to $10 \mathrm{~nm}$ gold particles (Jackson ImmunoResearch, West Grove, PA; 1:25 in TBST, pH 8.2), and counterstained with uranyl acetate and Sato's lead. When primary antiserum was omitted as a control, virtually no gold particles could be detected on the section; when normal serum was substituted for immune serum, sparse gold particles scattered across the section showed no discernible relationship to synapses.

Immunogold analysis. Grids were examined on a JEOL $200 \mathrm{CX}$ electron microscope at $80 \mathrm{kV}$ of accelerating voltage. At least three grids from three different rats were examined for each postsynaptic antigen considered (Table 2). Asymmetric synapses that had clearly outlined synaptic membranes and were labeled with at least one gold particle within $100 \mathrm{~nm}$ of the postsynaptic membrane were randomly selected and photographed (Table 2). Micrographs at 34,000× original magnification were digitized on a flatbed scanner. Locations of gold particles coding for each antigen were measured with NIH Image software running on a Macintosh platform. To define "axodendritic" position, the distance between the center of each gold particle and the outer leaflet of the postsynaptic membrane was measured (Fig. 1). Lateral synaptic position of a gold particle was defined as the distance from each end of the active zone to a line drawn perpendicular to the synaptic membrane and running through the center of the particle (for details, see Kharazia and Weinberg, 1997).

Despite its excellent spatial localization, immunogold has an inherent error because of the size of the particle and the antibody bridge, along with errors associated with the $\sim 100 \mathrm{~nm}$ section thickness; we estimate the maximal likely extent of these errors to be $\sim 25 \mathrm{~nm}$ (Kellenberger and Hayat, 1991). Because the PSD has a typical thickness of $\sim 50 \mathrm{~nm}$ (Martone et al., 1999), we restricted measurements of lateral position to gold particles lying within a 100 -nm-wide band, running between a line $25 \mathrm{~nm}$ presynaptic to the postsynaptic plasma membrane and a parallel line $75 \mathrm{~nm}$ cytoplasmic to the postsynaptic membrane (see Fig. $1 B$, dashed lines). Excel, Kaleidagraph, and CricketGraph software packages were used to generate graphs; Data Desk was used to compute statistics.

\section{RESULTS}

Material processed according to the osmium-free protocol we use for immunocytochemistry exhibited good ultrastructural preservation. Plasma membranes were sharply defined, and synaptic specializations were prominent and well delineated. In the forebrain, most of these specializations exhibited the prominent postsynaptic densities typical of excitatory glutamatergic synapses (Ottersen and Landsend, 1997). In supragranular layers of cerebral cortex, the large majority of synapses were of the axospinous type (Fig. 1A). At high magnification, features commonly described in osmium-treated material could be readily identified, including synaptic vesicles, presynaptic dense projections, and the subsynaptic web extending from the PSD into the cytoplasm (Fig. $1 B)$. The postsynaptic density is especially prominent in this 

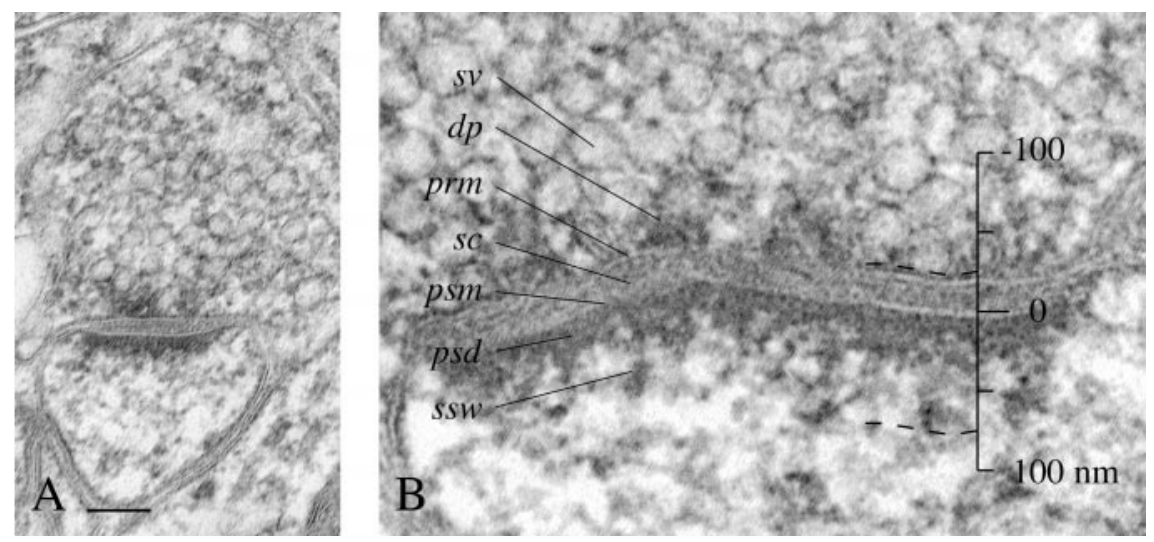

Figure 1. A, An axospinous cortical synapse of the simple (unperforated) asymmetric type, which exhibits a prominent PSD. Scale bar, $100 \mathrm{~nm}$. B, Highermagnification view of another asymmetric synapse. The good ultrastructural preservation achieved with the osmium-free fixation protocol used here permits study of the spatial relationship of the elements of the synapse at high resolution. Measurements of immunogold labeling were performed relative to the extracellular face of the postsynaptic membrane $(0 \mathrm{~nm})$, within the region $25 \mathrm{~nm}$ "outside" the postsynaptic membrane $(-25 \mathrm{~nm})$ and $75 \mathrm{~nm}$ "inside" the membrane (dashed lines). $d p$, Presynaptic dense projections; prm, presynaptic membrane; $p s d$, postsynaptic density; psm, postsynaptic membrane; sc, synaptic cleft; $s s w$, subsynaptic web; $s v$, synaptic vesicle.

material, typically extending $25-50 \mathrm{~nm}$ into the cytoplasm beyond the postsynaptic membrane.

Gold particles coding for seven different proteins contributing to the biochemically defined NMDA receptor complex accumulated mainly over the PSD (Fig. 2). In contrast, particles coding for synaptophysin, a protein associated with synaptic vesicles, accumulated over the presynaptic terminal (Fig. 2), documenting the specificity of this postsynaptic labeling. Each of the postsynaptic proteins was also associated with somatic endoplasmic reticulum and dendritic microtubules (data not shown). Several of the proteins, especially DLC, were also found over the spine apparatus (Fig. 2) (Naisbitt et al., 2000).

Close examination of Figure 2 hints at subtle differences in the synaptic organization of these seven proteins. To provide objective evidence of possible differential organization, we examined the distribution of immunogold particles compiled from a randomly selected sample of asymmetric synapses. We first wanted to determine whether labeling for each protein was coextensive with the synapse. We reasoned that if antigen were associated with the plasma membrane per se, there should be just as high a density of particles associated with the plasma membrane away from the synaptic specialization as at the synapse. Aside from modest variations in background noise and labeling efficiency between Epon-embedded and Lowicryl-embedded material, there were no obvious differences among animals in the pattern of labeling. We therefore pooled immunogold data from all seven animals. For each of the seven putative postsynaptic antigens tested, gold particles close to the synaptic membrane concentrated at the synaptic specialization, declining rapidly past the lateral edge of the PSD (Fig. $3 A$ ).

We wanted to test whether each antigen concentrated just inside the postsynaptic plasma membrane (rather than, e.g., uniformly within the dendritic cytoplasm or preferentially within the synaptic cleft). Therefore, we examined the axodendritic distribution of gold particles lying within the lateral borders of the synaptic specialization, for each of the seven antigens tested. Figure $3 B$ documents that each of the antigens was at the highest level in the region just cytoplasmic to the postsynaptic membrane. Although the peak for each graph is broadened by measurement error, it is apparent that some proteins (especially DLC) exhibited broader distributions than did the others. Likewise, although all of the peaks were inside the postsynaptic membrane, careful inspection reveals that some lay closer to the plasma membrane than did others.

Notwithstanding the intrinsic measurement noise, we reasoned that as long as this error was random and unbiased, averaging would reduce its magnitude, thus substantially increasing the accuracy of estimates of axodendritic position. Results of this procedure are given in Table 3. These data reveal a laminar organization of proteins within the PSD; some (PSD-95 and
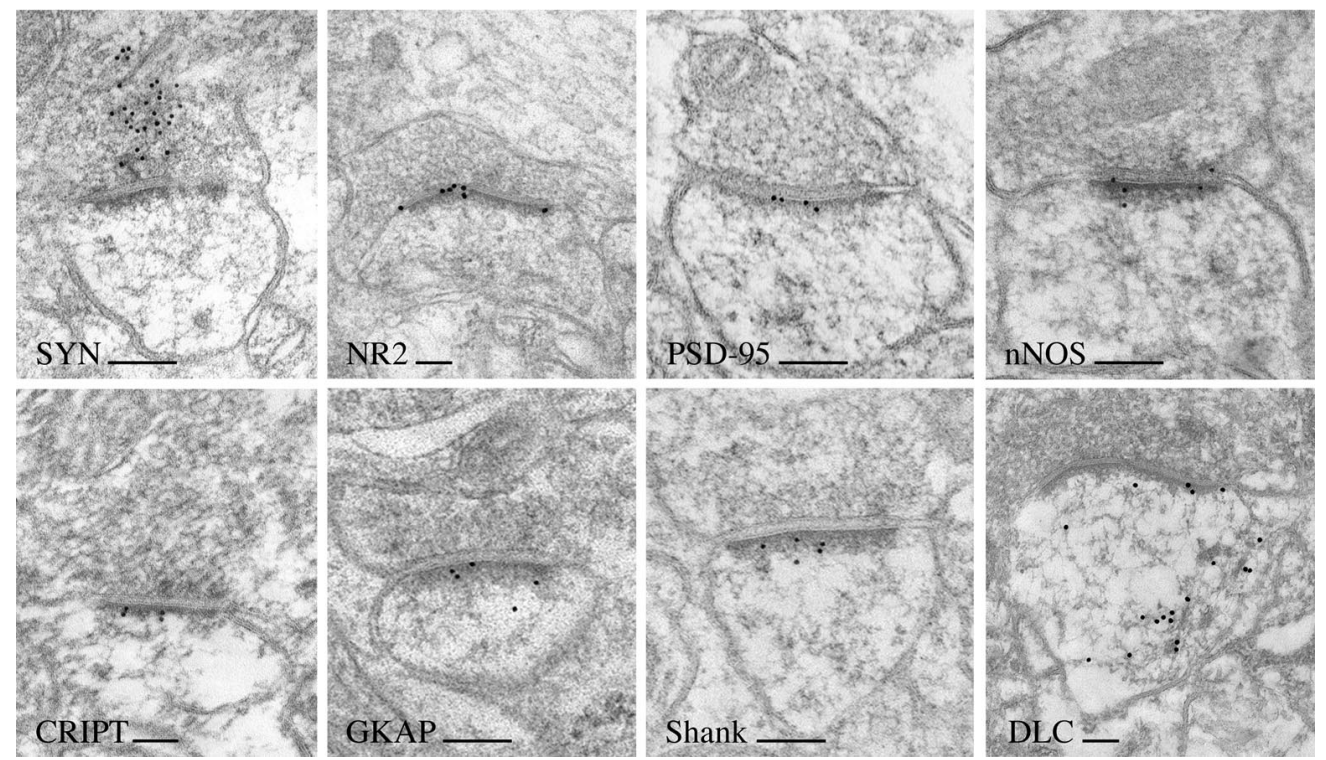

Figure 2. Postembedding immunogold labeling for the proteins studied here. Each of the NMDA receptor-related proteins shows labeling associated with the PSD, in contrast to synaptophysin (SYN; upper left). Labeling for DLC (lower right) is also over the spine apparatus. Scale bars, $100 \mathrm{~nm}$. 

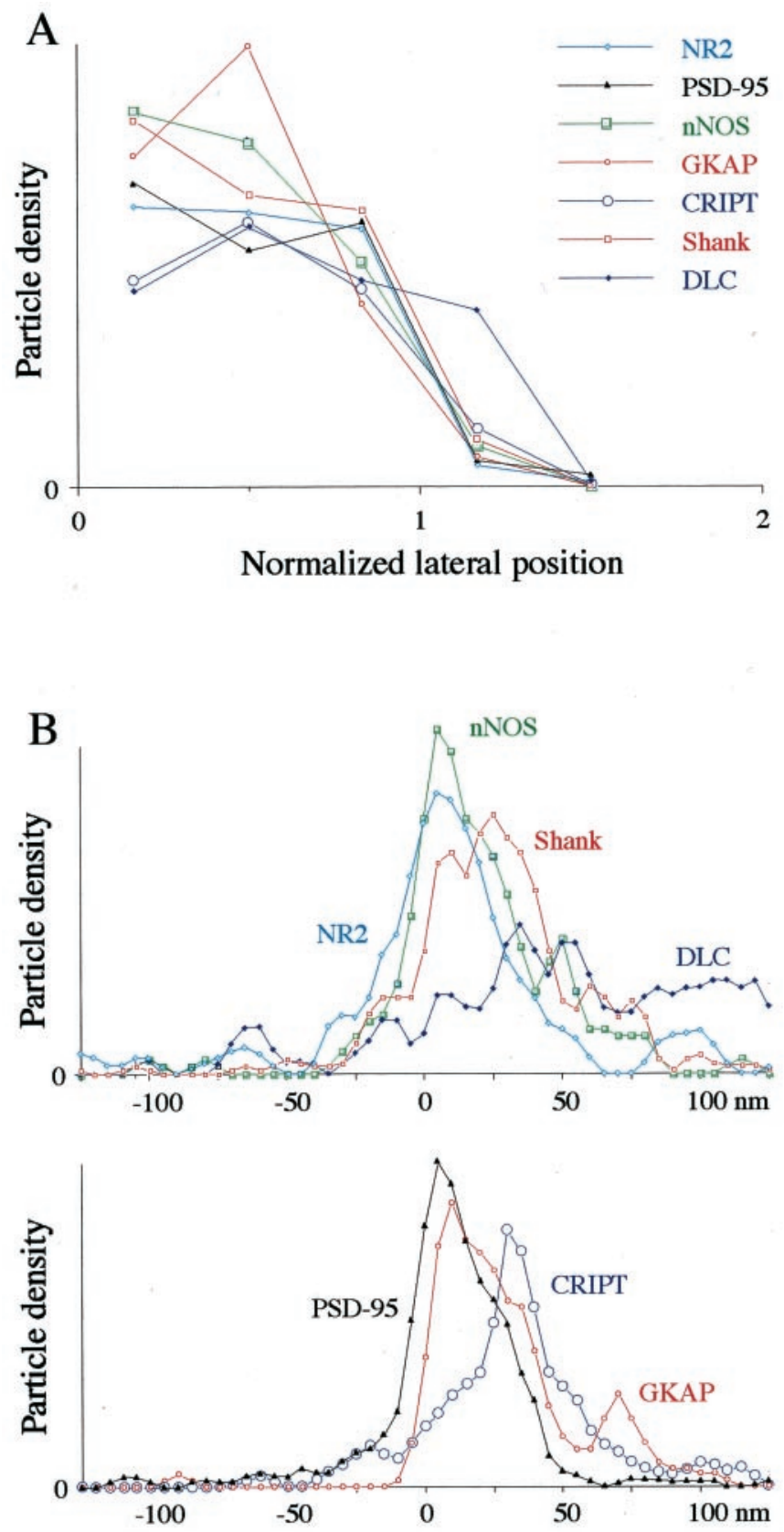

Axodendritic position

Figure 3. A, Graph shows "lateral" position of gold particles, tangentially along the postsynaptic membrane, for each protein studied. Only gold particles lying in a band running between -25 and $+75 \mathrm{~nm}$ from the plasma membrane of the postsynaptic profile were considered. Lateral positions were normalized, so that 0 corresponds to the center of the synapse and 1.0 corresponds to its edge. Data shown were put into six bins from 0 to 2.0; thus, for example, the third data point includes all particles between 0.67 and 1.0. Labeling for all seven antigens was mainly within the lateral borders of the synapse. $B$, Axodendritic distributions of each of the seven proteins studied are shown (for clarity, two graphs are used). Only gold particles within the width of the PSD and lying in a band running between -25 and $+75 \mathrm{~nm}$ from the postsynaptic plasma membrane were considered. Data were put into $5 \mathrm{~nm}$ bins; for graphing, data were smoothed with a digital filter (3-point-weighted running average). All seven antigens concentrate in the PSD; some (especially DLC) exhibit broader distribution than the others, extending into the spine cytoplasm.
Table 3. Axodendritic position of labeling for seven postsynaptic antigens

\begin{tabular}{lllc} 
Antigen & $\begin{array}{l}\text { Depth in PSD } \\
\text { mean } \pm \text { SE }\end{array}$ & SD & $\begin{array}{l}\text { Interquartile } \\
(25 \text { th-75th\%) }\end{array}$ \\
\hline NR2 & $11.2 \pm 1.5(142)$ & 17.6 & $0-22$ \\
PSD-95 & $11.9 \pm 1.2(166)$ & 15.1 & $0-24$ \\
nNOS & $18.1 \pm 2.1(96)$ & 20.7 & $4-32$ \\
CRIPT & $27.9 \pm 2.3(85)$ & 21.5 & $16-40$ \\
GKAP & $25.9 \pm 2.1(94)$ & 20.0 & $10-36$ \\
Shank & $24.1 \pm 1.7(180)$ & 22.7 & $8-39$ \\
DLC & $31.5 \pm 3.2(61)$ & 24.7 & $14-52$
\end{tabular}

Axodendritic positions are listed (in nanometers) for gold particles coding for each antigen. The number of particles measured is in parentheses; only particles within the lateral extent of the synaptic density and lying in a band running from -25 to +75 $\mathrm{nm}$ from the postsynaptic membrane (Fig. 1) were included. Interquartile ranges provide a measure of sample variability. nNOS lies farther from the postsynaptic membrane than NR2 or PSD-95 and closer than CRIPT, GKAP, Shank, or DLC.

Table 4. $\mathrm{Z}$ scores for differences in axodendritic position

\begin{tabular}{lllllll} 
Antigen & NR2 & PSD-95 & nNOS & CRIPT & GKAP & Shank \\
\hline PSD-95 & -0.65 & & & & & \\
nNOS & -2.39 & -2.10 & & & & \\
CRIPT & $-6.00^{* * *}$ & $-6.30^{* * *}$ & $-3.43^{*}$ & & & \\
GKAP & $-5.24 * * *$ & $-5.24 * * *$ & -2.61 & -1.52 & & \\
Shank & $-5.30^{* * *}$ & $-5.37^{* * *}$ & -2.35 & -1.79 & -0.25 & \\
DLC & $-5.66^{* * *}$ & $-5.88^{* * *}$ & $-3.68^{* *}$ & -1.29 & -2.03 & -2.44
\end{tabular}

$\mathrm{Z}$ scores were computed by use of the Mann-Whitney $U$ test to assess significance of differences in axodendritic positions, for all pairs of antigens tested. ${ }^{*} p<0.05$; ${ }^{* *} p<0.01 ; * * * p<0.001$ (Bonferroni correction for multiple comparisons).

NR2) lay close to the plasma membrane, others (CRIPT, GKAP, Shank, and DLC) lay markedly farther away, and still others (nNOS) lay in a position intermediate between the two. The exact level of significance for these data depends on the assumptions of the statistical model, but a robust nonparametric analysis suggests that many of the differences observed were unlikely to have arisen by chance (Table 4), supporting a laminar organization of the proteins within the PSD.

The SEs of mean positions of the antigens listed in Table 3 range from 1.2 to $3.2 \mathrm{~nm}$, substantially smaller than the dimensions of many proteins. This measurement precision suggests that the axodendritic data might enable us to infer details of the organization of the NMDA receptor complex and in favorable cases might even give clues as to the orientation of individual protein molecules within the complex. We therefore used these data, along with published data on molecular weights, binding partners, and binding sites, to construct a physically realistic model of the architecture of the protein assembly (Fig. 4). Although some aspects of this diagram are arbitrary, the diagram is constrained by available data. For example, because no data are available that directly address the orientation of PSD-95 within the complex, it may seem that its depiction pointing away from the membrane is purely arbitrary. However, the orientation is constrained by (1) its N-terminal palmitoylation (Craven et al., 1999), (2) the immunogold-defined location of its antigenic region, and (3) the measured location of CRIPT, one of its binding partners. Although schematic and incomplete (at least 10 more proteins biochemically associated with the NMDA receptor complex have been described previously), this diagram may provide a more accurate view of the supramolecular architecture of the NMDA complex than has been available previously. 


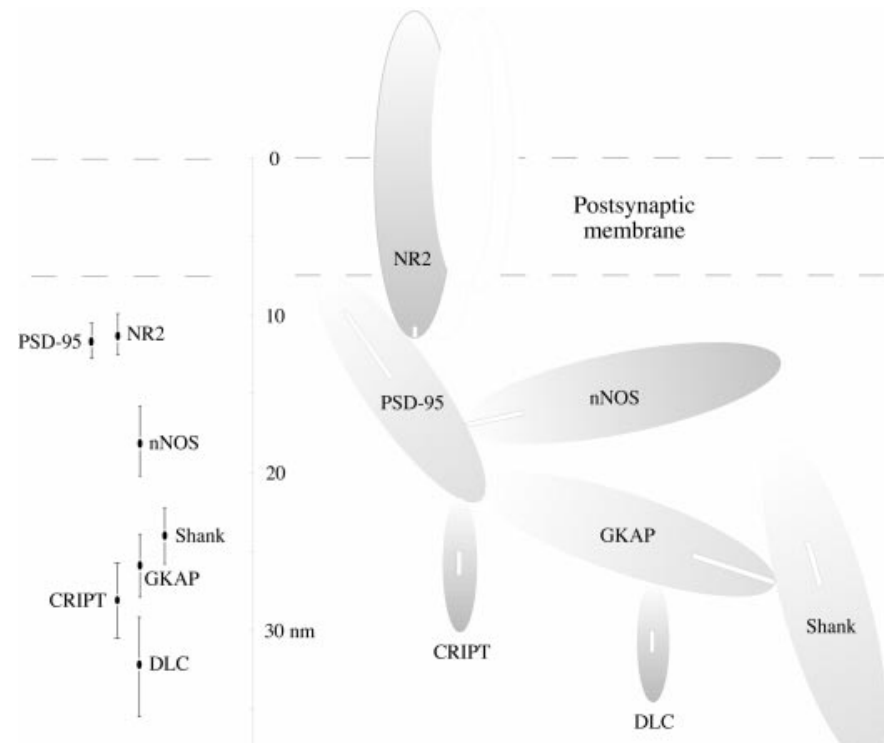

Figure 4. Left, On this side of the scale is the mean $( \pm$ SE) axodendritic position of gold particles coding for the seven proteins studied. Note that the majority of gold particles lie outside the SE bars (see Fig. $3 B$ ). Only gold particles within the region from -25 and $+75 \mathrm{~nm}$ of the postsynaptic membrane and laterally within the width of the PSD were included in computations (see Fig. 2); data are from Table 3. PSD-95 and the C terminal of NR2 lie just inside the postsynaptic membrane; nNOS lies in the central part of the PSD; and Shank, GKAP, CRIPT, and DLC lie on the cytoplasmic side of the PSD. Right, On this side of the scale is a model of the architectural layout of the seven proteins studied based on our pooled data. The proteins are drawn as ellipses of uniform shape, depicting prolate spheroids whose volumes are proportional to their molecular weights; thus, the length of each ellipse is proportional to (molecular weight $)^{1 / 3}$. The $\mathrm{N}$ terminal of each protein is light; the $\mathrm{C}$ terminal is dark. Proteins reported to bind directly to each other in vitro are shown touching. It is not yet clear whether all these proteins are found at the same synapse. The NMDA receptor is depicted as a tetramer containing NR1 and NR2 subunits. Ellipsoids are oriented so that the protein regions recognized by the antibodies (white bars) lie at distances from the postsynaptic membrane experimentally measured by immunogold (left side of figure). Positions of domains within molecules correspond to their location in the primary sequence and do not necessarily represent their true tertiary structure. The model also includes available biochemical data about molecular interactions. For example, the N terminal of PSD-95, which is palmitoylated, is shown touching the postsynaptic membrane; GKAP, which binds with its C terminal to the PDZ domain of Shank (amino acids 541-602 of 1740), is depicted touching Shank at a point approximately one-third of the way from its $\mathrm{N}$ terminal.

\section{DISCUSSION}

Elucidation of intermolecular interactions at the synapse is a central task of molecular neurobiology (Kennedy, 2000). X-ray crystallography can solve protein structures at the atomic scale but is poorly suited to study membrane-bound protein complexes vital for synaptic function. High-resolution cryoelectron microscopy has been used to visualize the opening of the acetylcholine receptor (Unwin, 1995), but this technically challenging method requires purified in vitro samples. A recent study harnessed multiple approaches, including preembedding immunogold EM, to reveal the supramolecular architecture of the nuclear pore complex in yeast (Rout et al., 2000). We here use postembedding immunoelectron microscopy to elucidate aspects of the mesoscale organization of the NMDA receptor complex in the adult neocortex. Although this method has limited spatial resolution, it can in principle be applied to most protein assemblies, including those intimately bound to membranes.
Qualitatively similar immunogold results have been reported previously for individual antigens by our laboratory and others. In the present work, we studied the organization of multiple proteins, analyzing data from each antigen concurrently. By thus eliminating several potential sources of systematic error, it becomes possible to compare axodendritic positions for each antigen directly. The embedding method we have used may be less sensitive than techniques involving slam freezing and lowtemperature embedding in Lowicryl resins, although both methods yield generally similar results (Valtschanoff et al., 1998; Petralia et al., 1999). However, for our purpose, sensitivity is less important than unbiased sampling of antigen. The strong aldehyde fixation we used causes massive cross-linking, and therefore proteins within the PSD are unlikely to migrate significantly during embedding and immunoprocessing. Therefore, the methods used here are likely to provide a reasonably accurate picture of antigen distribution in vivo.

The expected error intrinsic to the immunogold method may be up to $\pm 25 \mathrm{~nm}$ (Kellenberger and Hayat, 1991). Assuming unbiased sampling, the law of large numbers suggests that the error in mean position should be reduced by an order of magnitude by averaging data from 100 gold particles; this estimate is consistent with the SEs reported in Table 3. Even greater accuracy might be possible with larger samples or further refinements of technique (e.g., smaller gold particles, direct conjugation of the primary antibody). However, biological variability in the location of epitopes also contributes to the variance of the measurements. This biological variability will be lost in the averaging procedure, and thus the graph in Figure $3 B$ reveals features of the supramolecular organization not apparent in Table 3, like the greater dispersion of DLC than the other proteins studied. We interpret this to imply that significant fractions of DLC may not be bound to GKAP. Indeed, electron micrographs show substantial labeling of the spine apparatus, which lies at some distance from the PSD (Fig. 2) (cf. Naisbitt et al., 2000).

The diagram shown in Figure 4 is only an initial effort to provide a spatially accurate impression of the organization of the NMDA receptor complex. Several sources of axodendritic error remain. For example, the tortuous three-dimensional shape of a spine implies that the distance measured is not truly orthogonal to the plane of synaptic apposition, especially for antigens far from the postsynaptic membrane, consistent with the generally larger SDs observed for antigens lying farther from the PSD (Table 3). Likewise, DLC is found at appreciable concentrations beyond the PSD, and inadvertent inclusion of some of this labeling may exaggerate its mean axodendritic distance. The epitope data provided in Table 1 are only approximate, leading to further inaccuracies. Finally, the protein structures given are primarily guesswork; we eagerly await x-ray crystallographic data that can be used to refine the model.

The diagram gives a sense of crowding, accentuated by the many components of the NMDA receptor complex not shown in this diagram, including $\alpha$-actinin, tubulin, spectrin, neuroligin, calmodulin, yotiao, CaM kinase II, Raf-1, ErbB-4, SynGAP, synaptic scaffolding molecule, nArgBP2, mammalian LIN-7, adenomatous polyposis coli tumor suppressor, and Homer, among others (Adam and Matus, 1996; Irie et al., 1997; Wyszynski et al., 1997, 1998; Chen et al., 1998; Gardoni et al., 1998; Hirao et al., 1998; Kim et al., 1998; Lin et al., 1998; Jo et al., 1999; Kawabe et al., 1999; Tu et al., 1999; Garcia et al., 2000; Yanai et al., 2000; Yao et al., 2000). Although additional elements of the NMDA receptor complex continue to be identified, it will be important 
also to define its stoichiometry and its heterogeneity to achieve a satisfactory understanding of its organization. The receptor complex in vivo exists in three dimensions, helping to relieve the crowding. Likewise, not every NMDA-related protein is present at every PSD; for example, the PSD protein Citron is selectively expressed by GABAergic neurons (Zhang et al., 1999). Recent data on the distribution of AMPA receptor-binding proteins suggest possible heterogeneity of the NMDA receptor complex even for adjacent synapses onto the same dendrite (Burette et al., 2001).

On the other hand, each of the NMDA receptor subunits is likely to be associated with a cytoplasmic assembly of similar complexity; moreover, some of the cytoplasmic proteins studied here may be oligomers in vivo [e.g., NOS (Hallmark et al., 1999)]. Thus, it seems likely that a sizable fraction of the protein packed within the PSD is associated with the NMDA receptor complex. We presume that this dense packing accounts for the observed electron density of the PSD; the less electron-dense postsynaptic specialization of GABAergic inhibitory synapses suggests that GABA receptors contain a far less complex intradendritic assembly. Exceptionally dense packing of proteins at the excitatory PSD may explain the difficulties observed in preembedding immunostaining of the synapse, except after weak fixation or proteolytic treatment (Burette et al., 1999; Fukaya and Watanabe, 2000; Valtschanoff et al., 2001).

The topological organization of the receptor complex as defined by yeast two-hybrid screens and coimmunoprecipitation (Kim and Huganir, 1999; Sheng and Pak, 2000) is consistent with our data. However, these biochemical methods cannot provide the spatial information provided in the present study. Although the data assembled in Figure 4 are only preliminary, this model may provide new insights into the trafficking and function of the NMDA receptor complex. It is intriguing, for example, that CRIPT [shown recently to be essential for the clustering of PSD-95 and GKAP in cultured neurons (Passafaro et al., 1999)] is on the cytoplasmic side of the PSD. It is not surprising the DLC lies at the cytoplasmic edge of the complex, considering its likely role in trafficking, but it may seem puzzling that DLC (identical to protein inhibitor of nNOS) has been proposed as an endogenous inhibitor of nNOS (Jaffrey and Snyder, 1996; but see Rodriguez-Crespo et al., 1998). In fact, our data support an unusually wide distribution of DLC, so that although its highest concentration is at the cytoplasmic side of the PSD (extending into the spine cytoplasm), a significant fraction is also found closer to the membrane, permitting a possible interaction with nNOS. Our data are also consistent with the possibility that nNOS may be positioned close to the NMDA receptor pore, where it may be directly exposed to calcium fluxes. This orientation, which would be predicted by evidence from cultured neurons that nNOS is selectively activated by NMDA receptor activation, over other stimuli that also raise intracellular $\left[\mathrm{Ca}^{2+}\right]$ (Kiedrowski et al., 1992), points to the likely importance of supramolecular organization in the regulation of calcium-signaling pathways.

\section{REFERENCES}

Adam G, Matus A (1996) Role of actin in the organization of brain postsynaptic densities. Mol Brain Res 43:246-250.

Bassand P, Bernard A, Rafiki A, Gayet D, Khrestchatisky M (1999) Differential interaction of the tSXV motifs of the NR1 and NR2A NMDA receptor subunits with PSD-95 and SAP97. Eur J Neurosci 11:2031-2043.

Bernard V, Bolam JP (1998) Subcellular and subsynaptic distribution of the NR1 subunit of the NMDA receptor in the neostriatum and globus pallidus of the rat: co-localization at synapses with the GluR2/3 subunit of the AMPA receptor. Eur J Neurosci 10:3721-3736.

Brenman JE, Chao DS, Gee SH, McGee AW, Craven SE, Santillano DR, Wu Z, Huang F, Xia H, Peters MF, Froehner SC, Bredt DS (1996) Interaction of nitric oxide synthase with the postsynaptic density protein PSD-95 and alpha1-syntrophin mediated by PDZ domains. Cell 84:757-767.

Burette A, Wyszynski M, Valtschanoff JG, Sheng M, Weinberg RJ (1999) Characterization of GRIP-immunopositive neurons in rat brain. J Comp Neurol 411:601-612.

Burette A, Khatri L, Wyszynski M, Sheng M, Ziff EB, Weinberg RJ (2001) Differential cellular and subcellular localization of the AMPA receptor-binding protein and glutamate receptor-interacting protein. J Neurosci 21:495-503.

Chen HJ, Rojas-Soto M, Oguni A, Kennedy MB (1998) A synaptic Ras-GTPase activating protein (p135 SynGAP) inhibited by CaM kinase II. Neuron 20:895-904.

Cho K-O, Hunt CA, Kennedy MB (1992) The rat brain postsynaptic density fraction contains a homolog of the Drosophila discs-large tumor suppressor protein. Neuron 9:929-942.

Christopherson KS, Hillier BJ, Lim WA, Bredt DS (1999) PSD-95 assembles a ternary complex with the $N$-methyl-D-aspartic acid receptor and a bivalent neuronal NO synthase PDZ domain. J Biol Chem 274:27467-27473.

Collingridge GL, Watkins JC, eds (1994) The NMDA receptor, Ed 2. Oxford: Oxford UP.

Craven SE, Bredt DS (1998) PDZ proteins organize synaptic signaling pathways. Cell 93:495-498.

Craven SE, El-Husseini AE, Bredt DS (1999) Synaptic targeting of the postsynaptic density protein PSD-95 mediated by lipid and protein motifs. Neuron 22:497-509.

Devoto SH, Barnstable CJ (1989) Expression of the growth cone specific epitope CDA 1 and the synaptic vesicle protein SVP38 in the developing mammalian cerebral cortex. J Comp Neurol 290:154-168.

Dingledine R, Borges K, Bowie D, Traynelis SF (1999) The glutamate receptor ion channel. Pharmacol Rev 51:7-61.

Fukaya M, Watanabe M (2000) Improved immunohistochemical detection of postsynaptically located PSD-95/SAP90 protein family by protease section pretreatment: a study in the adult mouse brain. J Comp Neurol 426:572-586.

Garcia RA, Vasudevan K, Buonanno A (2000) The neuregulin receptor ErbB-4 interacts with PDZ-containing proteins at neuronal synapses. Proc Natl Acad Sci USA 97:3596-3601.

Gardoni F, Caputi A, Cimino M, Pastorino L, Cattabeni F, Di Luca M (1998) Calcium/calmodulin-dependent protein kinase II is associated with NR2A/B subunits of NMDA receptor in postsynaptic densities. J Neurochem 71:1733-1741.

Garner CC, Nash J, Huganir RL (2000) PDZ domains in synapse assembly and signaling. Trends Cell Biol 10:274-280.

Hallmark OG, Phung YT, Black SM (1999) Chimeric forms of neuronal nitric oxide synthase identify different regions of the reductase domain that are essential for dimerization and activity. DNA Cell Biol 18:397-407.

Hirao K, Hata Y, Ide N, Takeuchi M, Irie M, Yao I, Deguchi M, Toyoda A, Sudhof TC, Takai Y (1998) A novel multiple PDZ domaincontaining molecule interacting with $N$-methyl-D-aspartate receptors and neuronal cell adhesion proteins. J Biol Chem 273:21105-21110.

Hollmann M, Heinemann S (1994) Cloned glutamate receptors. Annu Rev Neurosci 17:31-108.

Irie M, Hata Y, Takeuchi M, Ichtchenko K, Toyoda A, Hirao K, Takai Y, Rosahl TW, Sudhof TC (1997) Binding of neuroligins to PSD-95. Science 277:1511-1515

Jaffrey SR, Snyder SH (1996) PIN: an associated protein inhibitor of neuronal nitric oxide synthase. Science 274:774-777.

Jo K, Derin R, Li M, Bredt DS (1999) Characterization of MALS/ Velis-1, -2, and -3: a family of mammalian LIN-7 homologs enriched at brain synapses in association with the postsynaptic density-95/NMDA receptor postsynaptic complex. J Neurosci 19:4189-4199.

Kawabe H, Hata Y, Takeuchi M, Ide N, Mizoguchi A, Takai Y (1999) nArgBP2, a novel neural member of ponsin/ArgBP2/vinexin family that interacts with synapse-associated protein 90/postsynaptic density95-associated protein (SAPAP). J Biol Chem 274:30914-30918.

Kellenberger E, Hayat MA (1991) Some basic concepts for the choice of methods. In: Colloidal gold: principles, methods, and applications, Vol 3 (Hayat MA, ed), pp 1-30. New York: Academic.

Kennedy MB (1997) The postsynaptic density at glutamatergic synapses. Trends Neurosci 20:264-268.

Kennedy MB (2000) Signal-processing machines at the postsynaptic density. Science 290:750-754.

Kharazia VN, Weinberg RJ (1997) Tangential synaptic distribution of NMDA and AMPA receptors in rat neocortex. Neurosci Lett 238:41-44.

Kharazia VN, Weinberg RJ (1999) Immunogold localization of AMPA and NMDA receptors in somatic sensory cortex of albino rat. J Comp Neurol 412:292-302. 
Kiedrowski L, Costa E, Wroblewski JT (1992) Glutamate receptor agonists stimulate nitric oxide synthase in primary cultures of cerebellar granule cells. J Neurochem 58:335-341.

Kim E, Niethammer M, Rothschild A, Jan YN, Sheng M (1995) Clustering of Shaker-type $\mathrm{K}+$ channels by interaction with a family of membrane-associated guanylate kinases. Nature 378:85-88.

Kim E, Naisbitt S, Hsueh Y-P, Rao A, Rothschild A, Craig AM, Sheng M (1997) GKAP, a novel synaptic protein that interacts with the guanylate kinase-like domain of the PSD-95/SAP90 family of channel clustering molecules. J Cell Biol 136:669-678.

Kim JH, Huganir RL (1999) Organization and regulation of proteins at synapses. Curr Opin Cell Biol 11:248-254.

Kim JH, Liao D, Lau LF, Huganir RL (1998) SynGAP: a synaptic RasGAP that associates with the PSD-95/SAP90 protein family. Neuron 20:683-691.

Kistner U, Wenzel BM, Veh RW, Cases-Langhoff C, Garner AM, Appeltauer U, Voss B, Gundelfinger ED, Garner CC (1993) SAP90, a rat presynaptic protein related to the product of the Drosophila tumor suppressor gene dlg-A. J Biol Chem 268:4580-4583.

Kornau HC, Schenker LT, Kennedy MB, Seeburg PH (1995) Domain interaction between NMDA receptor subunits and the postsynaptic density protein PSD-95. Science 269:1737-1740.

Lin JW, Wyszynski M, Madhavan R, Sealock R, Kim JU, Sheng M (1998) Yotiao, a novel protein of neuromuscular junction and brain that interacts with specific splice variants of NMDA receptor subunit NR1. J Neurosci 18:2017-2027.

Malenka RC, Nicoll RA (1999) Long-term potentiation-a decade of progress? Science 285:1870-1874.

Martone ME, Jones YZ, Young SJ, Ellisman MH, Zivin JA, Hu BR (1999) Modification of postsynaptic densities after transient cerebral ischemia: a quantitative and three-dimensional ultrastructural study. J Neurosci 19:1988-1997.

Migaud M, Charlesworth P, Dempster M, Webster LC, Watabe AM, Makhinson M, He Y, Ramsay MF, Morris RG, Morrison JH, O’Dell TJ, Grant SG (1998) Enhanced long-term potentiation and impaired learning in mice with mutant postsynaptic density-95 protein. Nature 396:433-439.

Naisbitt S, Kim E, Tu J, Xiao B, Sala C, Valtschanoff JG, Weinberg RJ, Worley P, Sheng M (1999) Shank, a novel family of postsynaptic density proteins that binds to the NMDA receptor/PSD-95/GKAP complex and cortactin. Neuron 23:569-582.

Naisbitt S, Valtschanoff JG, Allison DW, Sala C, Kim E, Craig AM, Weinberg RJ, Sheng M (2000) Interaction of the PSD-95/GKAP complex with myosin-V, mediated by dynein light chain DLC. J Neurosci 20:4524-4534.

Niethammer M, Kim E, Sheng M (1996) Interaction between the C terminus of NMDA receptor subunits and multiple members of the PSD-95 family of membrane-associated guanylate kinases. J Neurosci 16:2157-2163.

Niethammer M, Valtschanoff JG, Kapoor TM, Allison DW, Weinberg RJ, Craig AM, Schreiber SL, Sheng M (1998) CRIPT, a novel postsynaptic PDZ3-binding protein that links PSD-95 to tubulin. Neuron 20:693-707.

O'Brien RJ, Lau LF, Huganir RL (1998) Molecular mechanisms of glutamate receptor clustering at excitatory synapses. Curr Opin Neurobiol 8:364-369.

Ottersen OP, Landsend AS (1997) Organization of glutamate receptors at the synapse. Eur J Neurosci 9:2219-2224.

Passafaro M, Sala C, Niethammer M, Sheng M (1999) Microtubule binding by CRIPT and its potential role in the synaptic clustering of PSD-95. Nat Neurosci 2:1063-1069.

Petralia RS, Wang YX, Wenthold RJ (1994) The NMDA receptor subunits NR2A and NR2B show histological and ultrastructural localization patterns similar to those of NRI. J Neurosci 14:6102-6120.

Petralia RS, Wang Y-X, Sans N, Wenthold RJ (1999) Organization of glutamate receptors and associated proteins in the postsynaptic spine. Soc Neurosci Abstr 25:1237.

Phend KD, Weinberg RJ, Rustioni A (1992) Techniques to optimize post-embedding single and double staining for amino acid neurotransmitters. J Histochem Cytochem 40:1011-1020.

Phend KD, Rustioni A, Weinberg RJ (1995) An osmium-free method of
Epon embedment that preserves both ultrastructure and antigenicity for post-embedding immunocytochemistry. J Histochem Cytochem 43:283-292.

Racca C, Stephenson FA, Streit P, Roberts JD, Somogyi P (2000) NMDA receptor content of synapses in stratum radiatum of the hippocampal CA1 area. J Neurosci 20:2512-2522.

Rodriguez-Crespo I, Straub W, Gavilanes F, Ortiz de Montellano PR (1998) Binding of dynein light chain (PIN) to neuronal nitric oxide synthase in the absence of inhibition. Arch Biochem Biophys 359:297-304.

Rout MP, Aitchison JD, Suprapto A, Hjertaas K, Zhao Y, Chait BT (2000) The yeast nuclear pore complex: composition, architecture, and transport mechanism. J Cell Biol 148:635-651.

Scott K, Zuker CS (1998) Assembly of the Drosophila phototransduction cascade into a signaling complex shapes elementary responses. Nature 395:805-808.

Sheng M, Pak DT (2000) Ligand-gated ion channel interactions with cytoskeletal and signaling proteins. Annu Rev Physiol 62:755-788.

Sprengel R, Suchanek B, Amico C, Brusa R, Burnashev N, Rozov A, Hvalby O, Jensen V, Paulsen O, Andersen P, Kim JJ, Thompson RF, Sun W, Webster LC, Grant SG, Eilers J, Konnerth A, Li J, McNamara JO, Seeburg PH (1998) Importance of the intracellular domain of NR2 subunits for NMDA receptor function in vivo. Cell 92:279-289.

Takumi Y, Matsubara A, Rinvik E, Ottersen OP (1999) The arrangement of glutamate receptors in excitatory synapses. Ann NY Acad Sci $868: 474-482$

Tsunoda S, Zuker CS (1999) The organization of INAD-signaling complexes by a multivalent PDZ domain protein in Drosophila photoreceptor cells ensures sensitivity and speed of signaling. Cell Calcium $26: 165-171$

Tu JC, Xiao B, Naisbitt S, Yuan JP, Petralia RS, Brakeman P, Doan A, Aakalu VK, Lanahan AA, Sheng M, Worley PF (1999) Coupling of mGluR/Homer and PSD-95 complexes by the Shank family of postsynaptic density proteins. Neuron 23:583-592.

Unwin N (1995) Acetylcholine receptor channel imaged in the open state. Nature 373:37-43.

Valtschanoff JG, Phend K, Wenthold RJ, Sheng M, Weinberg RJ (1998) Expression of NMDAR2 receptor subunit in rat somatosensory cortex-synaptic localization and relationship with PSD proteins. Soc Neurosci Abstr 24:841.

Valtschanoff JG, Burette A, Wenthold R, Weinberg RJ (1999) Expression of NR2 receptor subunit in rat somatic sensory cortex: synaptic distribution and colocalization with NR1 and PSD-95. J Comp Neurol 410:599-611.

Valtschanoff JG, Burette A, Davare M, Leonard AS, Hell JW, Weinberg RJ (2000) Postsynaptic localization of SAP97 in cerebral cortex. Eur J Neurosci 12:3605-3614.

Weng G, Bhalla US, Iyengar R (1999) Complexity in biological signaling systems. Science 284:92-96.

Wyszynski M, Lin J, Rao A, Nigh E, Beggs AH, Craig AM, Sheng M (1997) Competitive binding of alpha-actinin and calmodulin to the NMDA receptor. Nature 385:439-442.

Wyszynski M, Kharazia V, Shanghvi R, Rao A, Beggs AH, Craig AM, Weinberg R, Sheng M (1998) Differential regional expression and ultrastructural localization of alpha-actinin-2, a putative NMDA receptor-anchoring protein, in rat brain. J Neurosci 18:1383-1392.

Yamada Y, Chochi Y, Ko JA, Sobue K, Inui M (1999) Activation of channel activity of the NMDA receptor-PSD-95 complex by guanylate kinase-associated protein (GKAP). FEBS Lett 458:295-298.

Yanai H, Satoh K, Matsumine A, Akiyama T (2000) The colorectal tumor suppressor APC is present in the NMDA-receptor-PSD-95 complex in the brain. Genes Cells 5:815-822.

Yao I, Ohtsuka T, Kawabe H, Matsuura Y, Takai Y, Hata Y (2000) Association of membrane-associated guanylate kinase-interacting protein-1 with Raf-1. Biochem Biophys Res Commun 270:538-542.

Zhang W, Vazquez L, Apperson M, Kennedy MB (1999) Citron binds to PSD-95 at glutamatergic synapses on inhibitory neurons in the hippocampus. J Neurosci 19:96-108.

Ziff EB (1997) Enlightening the postsynaptic density. Neuron 19:11631174. 